\title{
Industrial Revolution - Industry 4.0: Are German Manufacturing SMEs the First Victims of this Revolution?
}

\author{
Lutz Sommer \\ Department of Business Administration and Engineering, Albstadt-Sigmaringen University (Germany) \\ sommer@,bs-albsig.de
}

Received: April 2015

Accepted: September 2015

\section{Abstract:}

Purpose: Industry 4.0 represents a special challenge for businesses in general and for SMEs in particular. The study at hand will examine companies' awareness, readiness and capability to meet this challenge taking into account the special role of SMEs

Design/methodology/approach: The results of nine studies dealing with this range of topics are examined in the framework of a systematic review and compared with regard to the objective of the study at hand.

Findings: The review showed that, as a rule, there is an awareness concerning the relevance of the topic. The readiness and the capability to meet this challenge existin parts; however, they strongly depend on the enterprise size. The smaller SMEs are, the higher the risk that they will become victims instead of beneficiaries of this revolution.

Originality/value: Considering different studies concerning Industry 4.0 the article gives an insight into the dependence of the Industry 4.0 readiness in reference to the company size. This deepens the knowledge in adaption deficits German SME still have and opens different approaches for further research and action plans.

Keywords: industry 4.0, SME, digitalization, automation, internet of things 


\section{Introduction}

Industry 4.0 is a contemporary issue that concerns todays' industrial production as a whole and is meant to revolutionize it. The Platform Industry 4.0 interest group (Bundesverband Informationswirtschaft, Telekommunikation und neue Medien e.V., 2015) summarizes these changes as follows: "In the age of Industry 4.0 products inform machines autonomously what to do with them. In short, objects become intelligent. They have bar codes or RFID chips on their surface containing relevant information. Scanners or computers read out the data forward it online and make sure that the machines act appropriately. That way, the smart objects communicate. An internet of objects and services is created. The physical world and the virtual world merge into cyber-physical systems" (Bundesverband Informationswirtschaft, Telekommunikation und neue Medien e.V., 2015).

With regard to industry this means that the existing and, in parts, rather inflexible processes can be revolutionized by high-performance computers, a powerful internet and intelligent products and machines via active exchange of information. According to the Platform Industry 4.0 interest group production processes of the future will be decentralized, which means a shift away from today's still centrally controlled factories (Bundesverband Informationswirtschaft, Telekommunikation und neue Medien e.V., 2015).

Potential chances that could result from the implementation of Industry 4.0 in an industrial location like Germany are for example an increasing international competitiveness, an increased flexibility of production, a better adaption to customers' needs, new business models and the consideration of demographic change (Bundesverband Informationswirtschaft, Telekommunikation und neue Medien e.V., 2015).

Summarizing the statements above, the significance of Industry 4.0 for global competition taking into account the special conditions in industrial nations like Germany becomes evident to the reader. At the same time the question arises which qualifications companies need in order to take part in this revolutionary development. Here, the proponents of the revolution remain rather vague.

So, what is an industrial revolution? According to the German Bundeszentrale für politische Bildung (Federal Agency for Civic Education) (Bundeszentrale für politische Bildung, 2011) Industry 4.0 represents an industrial revolution with its typical social distortions. However, not the potential social distortions between employees and employers shall be discussed, but the potential distortions between the different enterprises involved. Will Industry 4.0 have an impact on Germany's business structure? Will there be winners or losers depending on companies' size? Will the already existing gap between large and small businesses increase and, accordingly, will it be a revolution of large enterprises at the expense of small enterprises? 
To answer these questions we will have to classify the German SMEs with regard to the German corporate landscape. The German Federal Statistical Office stated for 2012: "In 2012, the majority (99.3 percent $=2.2$ million) of all enterprises ranked among SMEs. 1.8 million were considered as micro-sized enterprises and only 16,000 ranked among large enterprises (Statistisches Bundesamt, 2014a). Out of the 16,000 large enterprises only 501 companies reached a turnover of more than 1 billion $€$ out of a total turnover of 1.9 trillion $€$ (Reuters, 2014; Statistisches Bundesamt, 2014a).

60 percent of the total number of 26.4 million employees work for SMEs (according to EUguidelines for the definition of SMEs) (Europäische Kommission, 2003; Statistisches Bundesamt, 2014a).

Taking into consideration the data published by the Federal Statistical Office in its Statistical Yearbook 2014 we obtain an even more detailed insight into Germany's corporate structure (Statistisches Bundesamt, 2014b):

- Total number: 2.2 million enterprises with a total turnover of 6.053 trillion $€$ and a SME share of 99.3 percent.

- Manufacturing trade: 484,494 enterprises with a turnover of 2,832 trillion $€$; thereof 203,644 enterprises in the processing trade with a turnover of 1,967 trillion $€$ and a SME share of 97.4 percent. Further manufacturing enterprises: mining industry, power and water supply industries and building industry.

Comparing the parameters number of enterprises, employed persons and turnover the following conclusion can be drawn (Statistisches Bundesamt, 2014b):

- Approximately 99 percent of all German enterprises are SMEs employing 60 percent of all employees in Germany. These SMEs and their employees generate 34 percent of the total turnover of all German enterprises.

- Approximately 1 percent of all German enterprises are large enterprises employing 40 percent of the German employees. These enterprises and their employees generate 66 percent of the total turnover of all German enterprises.

These figures illustrate that SMEs play an important role with regard to employment in Germany in general and in the manufacturing trade in particular. This leads to the conclusion that the successful implementation of an industrial revolution Industry 4.0 has to take place in large enterprises as well as in SMEs if this is meant to be more than false labelling. The interconnectedness of economy allows only a limited technological gap between large enterprises and SMEs with regard to Industry 4.0. Consequently, the question arises how wellprepared notably SMEs are for facing this predicted industrial revolution. Another aspect is that 
such an industrial upheaval could fail or could be slowed down despite willing and capable large enterprises due to incapable SMEs.

Thus, from a research point of view the question arises if SMEs in Germany are capable of taking an active part in this predicted revolution in the foreseeable future or if they risk becoming victims of this revolution for lack of adaptability. In addition, the question is if SMEs are aware of this risk.

This question is currently controversially discussed in science and in the media. Over the last years Industry 4.0 has become a mania. Apparently, things start sobering up now which means amongst other things that the platform Industry 4.0 is criticized for presenting many ideas but not enough results (Schmidt, 2014). Furthermore, complaints about SMEs' lack of interest in digitization are increasing (Schmidt, 2014). Indications for this tendency showed up early on the basis of surveys like the one published by the Business Performance Index Manufacturing SMEs in 2013 in which the lacking enthusiasm for this issue was pointed out (Dörfler, 2013). Already on the occasion of the Hannover Fair 2013 the consultancy Arthur D. Little headlined critically with regard to Industry 4.0: "Blessing or curse for the German industry?" thus turning against excessive euphoria (Arthur, 2013).

This situation was still unchanged at the beginning of 2014, as confirms a survey published by the WirtschaftsWochemagazine (Eisert, 2014a). According to this study two thirds of the interviewed manufacturing enterprises didn't know the concept of Industry 4.0 (Eisert, 2014a). In summer 2014, the Focus magazine headlined "Are German SMEs sleeping through a megatrend?" (Rickmann, 2014). The magazine criticizes that various studies point out relevant changes for SMEs in the context of Industry 4.0 but that German SMEs - in contrast to large enterprises - do not take action (Rickmann, 2014). Similar results can be found in a study published by the polling firm GfK Enigma stating that the chances of digitization are mostly ignored by SMEs (Knop, 2014). A survey published by the market research institute Pierre Audoin Consultants (PAC) in 2014 highlights the situation of 126 SMEs and arrives at the conclusion that: "SMEs are lacking confidence in information security and data protection. Without this confidence, the transformation of business and manufacturing processes threatens to stall - and Germany could fall behind in the fourth industrial revolution" (Eisert, 2014b). A more differentiated picture is drawn in a survey published by Staufen consultancy in December 2014 in which the so-called German Industry 4.0 index was examined (Herkommer, 2014). According to this survey "both, managers and staff are not very well prepared and eight out of ten enterprises feel abandoned by politics with regard to Industry 4.0" (Herkommer, 2014).End of 2014, the Manager Magazine even headlined provocatively: "Industry 4.0 - the big selfdeception" thus assuming that this form of industrial revolution might be too demanding for SMEs (Maier \& Student, 2015): "The backbone of German economy, SMEs, is sagging. In the meantime US champions, the Microsofts, Amazons and Googles of this world, enter the business with all their cleverness and acquisitiveness. With regard to making business with the 
consumer 4.0 they are already uncatchable and far ahead" (Maier \& Student, 2015). Only large enterprises like Bosch, Siemens or SAP could be capable of taking up the challenge successfully whereas according to Bullinger this doesn't apply to SMEs: "SMEs know that something has to be done, but they don't know how and where to start" (Maier \& Student, 2015).

In 2015, the human resources consultancy InterSearch Executive Consultants published their results concerning the issue of digital strategy in German enterprises stating that both, large enterprises and SMEs don't seem to pursue a comprehensive digitization strategy and that this is caused by management weaknesses (Maaß, 2015). The series of critical comments with regard to Industry 4.0 and SMEs continues in 2015. A study published by the IT service provider CSC comes to the conclusion that the issue of Industry 4.0 is simply too demanding for German SMEs (Perspektive Mittelstand, 2015). The Digital Business Readiness study from 2015 draws the following conclusion: "Many enterprises are lacking financial and often human resources too, to promote digital change internally. A large-scale survey published by the German Chambers of Commerce and Industry (Deutscher Industrie- und Handelskammertag, DIHK) with 2,000 interviewed enterprises illustrates how serious the digital deficit of SMEs really is (Unternehmer Position Nord, 2015). According to this study "only 27 percent of the 2,000 interviewed enterprises think that they are completely or almost completely digitally upto-date" (Unternehmer Position Nord, 2015).

These facts stand in contradiction to the hopes or rather the chances and potentials SMEs could generate in the context of Industry 4.0 as described by the representatives of the Industry 4.0 platform (Unternehmer Position Nord, 2015). The renowned German Economic Council, too, sees chances and potentials and requests SMEs to take action: "To date, the digitization of all fields of economy was mainly an issue of large enterprises. This attitude based on the misconception that things like Big Data, Cloud Computing or the Internet of Things were too complex, too expensive or too complicated for SMEs" (Wirtschaftsrat der CDU e. V., 2015).

From a research point of view the question arises how German manufacturing enterprises in general and SMEs in particular assess the relevance of the issue Industry 4.0 with regard to themselves. Are German manufacturing enterprises, or rather SMEs, generally lagging behind the development? And, if yes, are SMEs a victim of revolution already or are they simply clever enough to just observe the development with interest for the time being? Which relevance does the size of an enterprise have? Do enterprises in general or rather SMEs in particular take on a rather passive, observant or a proactive role? This leads to the following hypotheses:

Hypothesis 1: The more the digitization/implementation of Industry 4.0 is established in the industrial world in general the larger the readiness of German manufacturing enterprises to adapt to this development. 
Hypothesis 2: The smaller German manufacturing enterprises are the less they are engaged in the subject Industry 4.0.

Hypothesis 3: If Industry 4.0 would become the standard for production in Germany within the next few years, German manufacturing enterprises, according to their selfassessment, would be economically and technically prepared for it.

\section{Method}

As the empirical data at hand does not allow for a quantitative summary of the results (Ressing, Blettner \& Klug, 2009) and, therefore, a meta-analysis is not possible the survey is realized on the basis of a systematic review (Ressing et al., 2009; Stamm \& Schwarb, 1995).

The following methodical approach was taken for the selection of the empirical studies (Johannes Gutenberg Universität Mainz, Psychologisches Institut, 2012):

Criteria for the selection of empirical studies:

- Only quantitative empirical studies of the years 2013, 2014 and 2015 with a focus on "Industry 4.0/digitization" in connection with "German manufacturing SMEs" were selected.

- These studies had to be carried out and published by renowned scientific institutes / universities or consultancies.

- Studies focusing on both, large enterprises and SMEs were taken into account provided that this would allow for deductions with regard to SMEs.

- Studies working with information gathered in non-manufacturing enterprises were selected too, if they delivered a contribution allowing for deductions with regard to manufacturing SMEs.

- Empirical studies with questionable scientific foundation or too small sample sizes (=examined enterprises with $\mathrm{n}<100$; interviewed experts with $\mathrm{n}<25$ ) were excluded.

Research activities: In search of studies the author used internet search engines or libraries on the one hand. On the other hand, enterprises and institutions were interviewed directly.

List of studies included: The following nine empirical studies, based on a selection of 17 surveys, were included in the analysis: 


\begin{tabular}{|c|c|c|c|c|}
\hline No. & Name of the study/year & $\begin{array}{l}\text { Sector / size of } \\
\text { enterprise }\end{array}$ & Author / country & $\begin{array}{l}\text { Type / } \\
\text { volume }\end{array}$ \\
\hline A. & $\begin{array}{l}\text { Industrie } 4.0 \text { - Eine } \\
\text { Standortbestimmung der Automobil- u. } \\
\text { Fertigungsindustrie / } 2014 \text { (Kelkar, } \\
\text { Heger \& Dao, 2014) }\end{array}$ & $\begin{array}{l}\text { Manufacturing } \\
\text { enterprises / all } \\
\text { sizes }\end{array}$ & $\begin{array}{l}\text { MHP - A Porsche } \\
\text { Company \& Reutlingen } \\
\text { University / Germany }\end{array}$ & $\begin{array}{l}\text { Enterprises } \\
\text { interviewed / } \\
n=227\end{array}$ \\
\hline B. & $\begin{array}{l}\text { CSC-Studie Industrie } 4.0 \\
\text { Ländervergleich Dach / } 2015 \\
\text { (Computer Sciences Corp, 2015) }\end{array}$ & $\begin{array}{l}\text { Manufacturing } \\
\text { enterprises / all } \\
\text { sizes }\end{array}$ & $\begin{array}{l}\text { CSC Information } \\
\text { Technology / USA }\end{array}$ & $\begin{array}{l}\text { Enterprises } \\
\text { interviewed / } \\
n=900\end{array}$ \\
\hline C. & $\begin{array}{l}\text { IT Innovation Readiness Index / } 2014 \\
\text { (Freudenberg IT, 2014) }\end{array}$ & $\begin{array}{l}\text { Manufacturing } \\
\text { enterprises / large } \\
\text { SMEs ( }<4500 ;> \\
250 \text { employees) }\end{array}$ & $\begin{array}{l}\text { Pierre Audoin } \\
\text { Consultants GmbH / } \\
\text { Freudenberg IT SE \& Co. } \\
\text { KG / Germany }\end{array}$ & $\begin{array}{l}\text { Enterprises } \\
\text { interviewed / } \\
n=141\end{array}$ \\
\hline D. & $\begin{array}{l}\text { Industrie } 4.0 \text { - Chancen und } \\
\text { Herausforderungen der } \\
\text { viertenindustriellen Revolution / } 2014 \\
\text { (PricewaterhouseCoopers AG WPG, } \\
\text { 2014) }\end{array}$ & $\begin{array}{l}\text { Mostly } \\
\text { manufacturing } \\
\text { enterprises / all } \\
\text { sizes }\end{array}$ & $\begin{array}{l}\text { PricewaterhouseCoopers } \\
\text { AG (PWC) / Germany }\end{array}$ & $\begin{array}{l}\text { Enterprises } \\
\text { interviewed / } \\
n=235\end{array}$ \\
\hline E. & $\begin{array}{l}\text { DeutscherIndustrie } 4.0 \text { Index / } 2014 \\
\text { (Rohrbach, 2014) }\end{array}$ & $\begin{array}{l}\text { Mostly } \\
\text { manufacturing } \\
\text { enterprises / all } \\
\text { sizes }\end{array}$ & $\begin{array}{l}\text { Staufen AG Beratung / } \\
\text { Germany }\end{array}$ & $\begin{array}{l}\text { Enterprises } \\
\text { interviewed / } \\
n=140\end{array}$ \\
\hline F. & $\begin{array}{l}\text { Digitalisierung - Bedeutungfür den } \\
\text { MittelstandimAuftrag der DZ-Bank / } \\
2014 \text { (GfK Enigma, 2014) }\end{array}$ & $\begin{array}{l}\text { Mostly } \\
\text { manufacturing } \\
\text { enterprises / SMEs } \\
\text { (< } 250 \text { employees) }\end{array}$ & GfK Enigma / Germany & $\begin{array}{l}\text { Enterprises } \\
\text { interviewed / } \\
n=247\end{array}$ \\
\hline G. & $\begin{array}{l}\text { Wirtschaft } 4.0 \text { - GroßeChancen, } \\
\text { vielzutun / } 2015 \text { (DIHK, 2015) }\end{array}$ & $\begin{array}{l}\text { Different sectors / } \\
\text { all sizes }\end{array}$ & $\begin{array}{l}\text { Deutsche Industrie- und } \\
\text { Handels-kammertag } \\
\text { (DIHK) }\end{array}$ & $\begin{array}{l}\text { Enterprises } \\
\text { interviewed / } \\
n=1.849\end{array}$ \\
\hline H. & $\begin{array}{l}\text { Industrie } 4.0 \text { - Grundlagenwissen, } \\
\text { Experteninterviews und Pioniere / } 2014 \\
\text { (Schulze, 2014) }\end{array}$ & $\begin{array}{l}\text { Manufacturing } \\
\text { enterprises / SMEs } \\
\text { (< } 250 \text { employees) }\end{array}$ & Flyacts $\mathrm{GmbH}$ & $\begin{array}{l}\text { Experts } \\
\text { interviewed / } \\
\mathrm{n}=28\end{array}$ \\
\hline I. & $\begin{array}{l}\text { Große Anwenderstudie zu Industrie } 4.0 \\
\text { in Deutschland / } 2014 \text { (Weiß \& Zilch, } \\
\text { 2014) }\end{array}$ & $\begin{array}{l}\text { Different sectors / } \\
\text { all sizes }\end{array}$ & Experton GROUP & $\begin{array}{l}\text { Enterprises } \\
\text { interviewed / } \\
n=368\end{array}$ \\
\hline
\end{tabular}

Table 1. List of studies included in the survey

From the studies listed above, the studies $\mathrm{F}$ and $\mathrm{H}$ examined small German manufacturing SMEs. The studies A, B, C, D and E also examined German manufacturing SMEs; however, different sizes of enterprises were included in the studies. The studies $G$ and I were more general in character.

The analysis of the correlation between German manufacturing enterprises and Industry 4.0 was carried out from an economic-technical point of view following the Value Chain by M. Porter (Carnegie Mellon University, n.d.) on the one hand and from a psychological point of view by screening the expectations of the interviewees according to Ajzen (Ajzen, 2005; Ajzen \& Fishbein, 1980) on the other hand:

- Economic-technical level:

- primary activities like operations and logistics;

- $\quad$ support activities like investment, data processing or recruiting. 
- Psychological level:

- degree of familiarity with the subject;

- expectations with regard to chances and risks;

- awareness of the significance of the subject (Ajzen, 2005; Ajzen \& Fishbein, 1980).

\section{Research}

In the following, the results of the nine studies will be presented, subdivided into the two economic-technical and the three psychological focal topics. For this purpose, the results of the studies A to I (Computer Sciences Corp, 2015; DIHK, 2015; Freudenberg IT, 2014; GfK Enigma, 2014; Kelkar et al., 2014; PricewaterhouseCoopers AG WPG, 2014; Rohrbach, 2014; Schulze, 2014) will be analyzed.

\subsection{Primary Activities}

Operations and Logistics: The results of GfK Engima GmbH (study F) illustrate an increasing relevance of digital technologies for value-added processes in all enterprises. According to this study 51 percent of the interviewees rank the relevance of digital technologies as very important or important today and even 59 percent of the interviewees rate them as very important in the future (GfK Enigma, 2014). A striking fact, however, is that this value correlates with the size of the enterprise i.e. small enterprises rank the relevance of digital technologies significantly lower than large enterprises whereas the industrial sector apparently doesn't play an important role (GfK Enigma, 2014).

These results are confirmed by the survey of Pierre Audo in Consultants (study C) stating that even though Industry 4.0 technologies like for example Big Data, Internet of Things, Cloud Computing or Mobility increasingly find their way into manufacturing SMEs this progress is relatively small with regard to the global dynamics of markets as the rise by 0.5 points of the IT Innovation Readiness Index in 2014 proves (Freudenberg IT, 2014). The MHP survey (study A), too, documents that today the above mentioned Industry 4.0 technologies still have a low significance among the interviewees but that this value will rise significantly in the future (Kelkar et al., 2014). In addition to the above mentioned Industry 4.0 technologies enterprises already use technologies like for example cyber-physical systems or digital product memories which is an indication for the existence of Industry 4.0 pre-stages (Kelkar et al., 2014). In detail, study A comments on this: 
- today, rapid manufacturing technologies have a low significance value of 15 percent in the enterprises interviewed. However, this value will increase significantly up to 56 percent within the next five years;

- the level of automation and the implementation of cyber-physical systems will increase likewise

- simulations are standard practice in today's production processes and will become even more important (Kelkar et al., 2014).

\subsection{Support Activities}

Investment: GfK (study F) provides evidence that the willingness of enterprises to invest in digital technologies is low. 47 percent of all enterprises interviewed for the study said that they would only invest a maximum of 5 percent of the disposable investment capital. There was no noticeable trend regarding the size of enterprises or the industrial sector (GfK Enigma, 2014). These results are confirmed by MHP (study A) stating that currently the propensity to invest is generally low, however, there is an upward tendency (Kelkar et al., 2014).

The PWC survey (study D) delivers a different picture, as according to this study the enterprises interviewed are planning to invest on average 3.3 percent of their annual turnover in Industry 4.0 solutions (PricewaterhouseCoopers AG WPG, 2014). A possible reason for the deviation compared to the studies mentioned above could be the size of the enterprises interviewed. The PWC survey (study D) includes mostly large enterprises (51 percent) with a turnover of more than 0.5 billion $€$ whereas only 29 percent of the enterprises interviewed had a turnover of less than 100 million $€$ and therefore rather correspond to the upper turnover limit for SMEs of 50 million $€$ (PricewaterhouseCoopers AG WPG, 2014).

Data Processing: According to the study of Pierre Audoin Consultants (study C) one third of the interviewees assess the benefit of Big Data very critically (Freudenberg IT, 2014). This is attributed to the fact that on the one hand the cost/benefit ratio is seen as negative and that on the other hand there are other issues of vital importance like pressure to innovate and globalization (Freudenberg IT, 2014). The PWC survey (study D), too, states that the analysis and the use of data are seen as imperfect at the moment. However, this issue will gain in importance in the future, i.e. there will be a rise within the next five years from 49 to 90 percent (PricewaterhouseCoopers AG WPG, 2014).

Recruiting: The results of the GfK survey (study F) allow for the conclusion that 47 percent of all interviewed enterprises think that their employees are qualified for digital applications. Small enterprises are independently from the industrial sector less convinced than large enterprises (GfK Enigma, 2014). However, qualifications in this field will become increasingly 
important in recruiting processes in the future (GfK Enigma, 2014). In the survey published by Pierre Audoin Consultants (study C), too, recruiting problems are seen as a so-called threat scenario (Freudenberg IT, 2014). The study comes to the conclusion that "With the transformation in direction of Industry 4.0 the requirements regarding job and training profiles will change fundamentally" (Freudenberg IT, 2014). The MHP study (study A), too, points out that the qualification profile of production employees has to be adapted to meet the new challenges for example by means of study programs combining engineering and IT sciences (Kelkar et al., 2014).

According to the CSC survey (study B) 48 percent of the interviewees think that the job market is ill-prepared of rather ill-prepared for facing the fourth industrial revolution and fear skills shortages. However, despite the negative assessment of the job market situation most enterprises don't undertake training activities with regard to Industry 4.0 (Computer Sciences Corp, 2015).

The Staufen AG survey (study E), as well, assumes that the skills level of employees will have to be raised which will lead to an increase of highly qualified employees on the account of the unqualified employees (Rohrbach, 2014). Currently, the employees are ill-prepared for a potential implementation of Industry 4.0. The interviewees graded the situation with 3.7 (on a scale from 1 = excellent to 6 = unsatisfactory) (Rohrbach, 2014). Interestingly, despite these findings the majority of the interviewed enterprises (= 70 percent) don't offer in-house training courses (Rohrbach, 2014).

The DIHK survey (study $G$ ) arrives at the conclusion that the interviewees observe a massive qualification gap. Amongst other things more knowledge is required in the fields of IT security (61 percent of responses), handling of EDP systems (60 percent of responses) and process know-how (54 percent of responses) (DIHK, 2015).

\subsection{Familiarity with the Subject}

The results of the survey published by Flyacts (study $\mathrm{H}$ ) showed that 68 percent of the interviewed experts didn't know the term Industry 4.0 at all (Schulze, 2014). This is contradictory to the MPH survey (study A), in which 76 percent of all interviewees were familiar with the term Industry 4.0. Enterprises in the mechanical and plant engineering sector scored above average with 92 percent (Kelkar et al., 2014). The CSD survey (study B) interviewing a pool of 900 managers/decision makers from Germany, Austria and Switzerland about their awareness of Industry 4.0 delivers a more differentiated picture (Computer Sciences Corp, 2015). About 32 percent of the German interviewees knew the term and its meaning. Another 29 percent merely knew the term (Computer Sciences Corp, 2015). This 
information relativizes the results of the studies mentioned above and delivers a possible explanatory approach for the deviations.

The Experton GROUP survey (study I), too, examined the knowledge about Industry 4.0 and found out that 30 percent of the interviewees didn't know the subject at all. Another 29 percent of the interviewees knew the subject but didn't plan activities concerning this matter in the future (Weiß \& Zilch, 2014). Conspicuously, the size of the enterprises was relevant here, too: 44 percent of the enterprises with up to 500 employees didn't know the subject Industry 4.0 and 31 percent of them didn't want to deal with it in the future. Among the enterprises with more than 1000 employees only 17 percent didn't know the subject and only 26 didn't want to deal with it (Weiß \& Zilch, 2014).

\subsection{Expectations}

Chances: According to the GfK survey (study F) enterprises primarily expect an improvement of competitiveness and a reduction of costs through modern and flexible processes, whereas new marketing channels or business markets are not expected (GfK Enigma, 2014). The issue of raising efficiency from the perspective of cost reduction is, according to Pierre Audoin Consultants (study C) a challenge for all enterprises which they think they can accomplish by means of Industry 4.0. This statement is confirmed by study F (Freudenberg IT, 2014).

The MHP survey (study A) delivers a clear indication that 83 percent of the interviewees regard the implementation of Industry 4.0 as desirable. With Industry 4.0 , they expect to be able to increase their flexibility and react faster to customers' requests (Kelkar et al., 2014).

According to the CSC survey (study B) 61 percent of the interviewed enterprises see good chances for an implementation of Industry 4.0 in the near future through suitable activities like for example the installation of Industry 4.0-compatible facilities, operating processes and infrastructures (Computer Sciences Corp, 2015). Of the implementation of Industry 4.0 they primarily expect an increased efficiency ( $=51$ percent of all interviewees), cost reduction (= 46 percent of the interviewees) as well as increased productivity, customer satisfaction and competitiveness (Computer Sciences Corp, 2015).

The PWC survey (study D) delivers indications that with regard to the quantitative benefit enterprises particularly expect increased efficiency and cost reduction. Concerning the qualitative benefit enterprises expect an increase in customer satisfaction (PricewaterhouseCoopers AG WPG, 2014). The hopes mainly rest on digitized products and services or rather new digital business models that shall generate a cumulated sales increase of 12.5 percent within five years (PricewaterhouseCoopers AG WPG, 2014). 
According to the Staufen AG survey (study E) a large, or rather very large benefit is expected in the fields of production and logistics, especially with regard to flexibility (78 percent of the interviewees), adherence to schedules (79 percent) and quality of services and products (Rohrbach, 2014).

Risks: According to the GfK-analysis (study F) the risks of digitization / Industry 4.0 are mainly seen in connection with data security and a possibly increasing dependence on technology (GfK Enigma, 2014). This statement is confirmed by the Flyacts survey (study $H$ ) adding the assumption that SMEs' products and projects might be too individual and labor-intensive for Industry 4.0 technologies, like for example apps for production control (Schulze, 2014).

75 percent of the interviewees of the Pierre Audoin Consultants survey (study C) classify data security, particularly with regard to mechanical and plant engineering, as a high risk which considerably impedes the implementation of the cloud in enterprises (Freudenberg IT, 2014). As a consequence, 40 percent of the manufacturing enterprises interviewed reject Cloud Computing (Freudenberg IT, 2014).

The MHP survey (study A), too, analyzed risks and obstacles and found out that, in particular, doubts about the economic benefit and the lacking clearness with regard to the necessary processes and standardization have an inhibiting effect (Kelkar et al., 2014). There is general agreement (almost 100 percent) that data protection is highly problematic. Large enterprises tend to see the subject more critically than SMEs (Kelkar et al., 2014). A main concern is the complexity of IT-systems and the increasing operational networking (Kelkar et al., 2014).

The PWC survey (study D) delivers similar results concerning obstacles and risks of Industry 4.0. The following aspects are concretely mentioned: unclear economic benefit (46 percent of the responses), qualification of employees (30 percent), lacking standards and norms (26 percent) as well as legal aspects and low degree of maturity of Industry 4.0 technologies (PricewaterhouseCoopers AG WPG, 2014).

The Staufen AG survey (study E) comes to the conclusion that data protection, as already mentioned in other surveys, represents an important, or rather very important obstacle (83 percent of the responses) (Rohrbach, 2014).

According to the Experton GROUP survey (study I) the reasons for lacking interest of the interviewees in Industry 4.0 are amongst other things risks like for example costs, lacking IT infrastructure or different priorities (Weiß \& Zilch, 2014).

The DIHK survey (study G) states that IT security problems (59 percent of the responses), legal uncertainties (50 percent), inadequate qualification of employees and high investment costs (39 percent) represent the main obstacles and reservations (DIHK, 2015). 88 percent of the interviewees identify the increased information demand as a new challenge (DIHK, 2015). 


\subsection{Awareness}

Despite all affirmations of enterprises concerning the necessity of digitization for SMEs (82 percent full or large approval according to the GfK survey) only 49 percent of the interviewed enterprises have integrated digitization as part of their corporate strategy (GfK Enigma, 2014). An interesting aspect in this context is the result of the survey conducted among SME experts by Flyacts (study $\mathrm{H}$ ): 54 percent of the interviewees have a rather negative attitude towards Industry 4.0 (whereas only 25 percent have a rather positive attitude) which, compared to the GfK survey, makes the awareness of the issue Industry 4.0 look even worse (Schulze, 2014).

In contradiction to the studies mentioned above the survey of Pierre Audoin Consultants (study C) comes to the result that SMEs are already aware of Industry 4.0: "The values concerning the important foundation pillars of Industry 4.0 like for example machine data collection, plant data collection, the connection of MES (= Manufacturing Execution System) to commercial systems as well as automatic production processes have all increased significantly within one year" (Freudenberg IT, 2014). According to this survey the implementation of basic components of Industry 4.0 turns out to be as follows: machine and plant data collection $=68$ percent, MES connection $=67$ percent, intelligent production facilities $=52$ percent and decentralized automatic production processes $=17$ percent (Freudenberg IT, 2014). This divergence can only be explained by the deviation caused by different sizes of enterprises as studies $\mathrm{F}$ and $\mathrm{H}$ examined SMEs with up to 250 employees whereas study $\mathrm{C}$ examined enterprises with 250 to 4.500 employees.

Another insight into the awareness of enterprises is delivered by the MHP survey with regard to plant and machine manufacturers (study A) stating that 79 percent of the interviewees attach great importance to the Industry 4.0 issue. This awareness is obviously followed by action as 67 percent of the interviewees say that they are already actively dealing with the subject (Kelkar et al., 2014). However, only 46 percent of the interviewees deal with Industry 4.0 looking at the average, regardless of enterprise size or industrial sector (Kelkar et al., 2014). A more detailed analysis of the data delivered by the MHP survey gives more insight (Kelkar et al., 2014):

- 46 percent of the interviewees answer the question if they are actively dealing with Industry 4.0 in the affirmative provided that the differentiation concerning industrial sector and enterprise size is disregarded.

- The same question is answered in the affirmative by 67 percent of all machine and plant manufacturers.

- If the total of the interviewees is subdivided into three size ranges (= less than 1,000 employees, 1,001 to 9,999 employees, more than 10,000 employees) values of 39 
percent, 44 percent and 52 percent are obtained (Kelkar et al., 2014). In other words: industrial sector and enterprise size definitely influence the results.

The CSC survey (study B) found out that 63 percent of the interviewees are aware of the importance of Industry 4.0 and that 51 percent of them think to be very well or well-prepared for it (Computer Sciences Corp, 2015).

The PWC survey (study D), too, analyzing the present and the future degree of digitization, comes to the conclusion that digitization of the horizontal and vertical value added chain with values of 24 percent and 20 percent is obviously relevant today already for the interviewed enterprises. However, it will become much more important within the next few years as the interviewed enterprises are explicitly planning an extension to 86 percent and 80 percent within five years (PricewaterhouseCoopers AG WPG, 2014). However, the degree of digitization depends on the enterprise size, that means that large enterprises with a turnover of more than 5 billion $€$ want to reach 93 percent and enterprises with a turnover of less than 100 million want to reach about 82 percent (PricewaterhouseCoopers AG WPG, 2014).

The Staufen AG survey (study E) comes to the conclusion that 34 percent of the interviewees haven't thought about Industry 4.0 at all yet and that 39 percent observe or analyze the issue. That means that only 25 percent of the interviewees deal with the issue intentionally and intensely (Rohrbach, 2014).

The Experton GROUP survey (study I) states that currently on average 19 percent of the SMEs deal with Industry 4.0 actively and 22 percent are analyzing it. Small SMEs show a low awareness of Industry 4.0. That means that only about 10 percent of the interviewed SMEs with less than 500 employees work actively in Industry 4.0 projects and 17 percent are analyzing and observing the issue. SMEs with more than 1.000 employees, on the other hand, show an activity value of 30 percent and an observation value of 26 percent (Weiß \& Zilch, 2014).

The DIHK survey (study G) confirms likewise that 94 percent of all interviewees and 94 percent of the manufacturing enterprises are aware of the influence of digitization (DIHK, 2015). When asked about their self-assessment 27 percent of all enterprises claim to be fully or almost fully developed with regard to digitization (DIHK, 2015). However, one has to differentiate between industrial sectors and enterprise sizes:

- industry rates itself at a value of 26 percent and the IT sector sees itself at a value of 71 percent; large enterprises with more than 1,000 employees rate themselves at a value of 34 and SMEs with less than 500 employees see themselves at a value of 26 percent (DIHK, 2015). 


\section{Discussion}

The research results at hand allow for drawing the following conclusions for the hypotheses.

Hypothesis 1 examined if German manufacturing enterprises in general are ready to face or rather to adapt to Industry 4.0. This can be affirmed. Substantiation is delivered by a detailed comparison of the studies.

\begin{tabular}{|c|c|c|}
\hline Study & Statements concerning Hypothesis 1 & Source \\
\hline$F$ & $\begin{array}{l}82 \text { percent of the interviewees fully or widely consent to the } \\
\text { necessity of digitization in SMEs; an adaptation of the corporate } \\
\text { strategy did not yet take place in } 52 \text { percent of the interviewed } \\
\text { enterprises }\end{array}$ & (GfK Enigma, 2014) \\
\hline $\mathbf{H}$ & $\begin{array}{l}25 \text { percent of the interviewees have a rather positive attitude } \\
\text { concerning Industry } 4.0\end{array}$ & (Schulze, 2014) \\
\hline C & $\begin{array}{l}\text { Adaption to Industry } 4.0 \text { is visible due to implementation in } \\
\text { enterprises, e.g. } 68 \text { percent of the interviewees already have } \\
\text { machine and plant data acquisition }\end{array}$ & (Freudenberg IT, 2014) \\
\hline $\mathbf{A}$ & $\begin{array}{l}79 \text { percent of the interviewed machine and plant manufacturers } \\
\text { attach very high / high importance to Industry } 4.0 ; 67 \text { percent are } \\
\text { already actively implementing it }\end{array}$ & (Kelkar et al., 2014) \\
\hline B & $\begin{array}{l}63 \text { percent of the interviewees are aware of the importance of } \\
\text { Industry } 4.0\end{array}$ & (Computer Sciences Corp, 2015) \\
\hline D & $\begin{array}{l}\text { The interviewees intend to increase the digitization of the value } \\
\text { added chain from } 24 \text { to } 86 \text { percent within the next five years }\end{array}$ & $\begin{array}{l}\text { (PricewaterhouseCoopers AG } \\
\text { WPG, 2014) }\end{array}$ \\
\hline E & $\begin{array}{l}25 \text { percent of the interviewees actively deal with Industry } 4.0 ; 39 \\
\text { percent observe and analyze the issue }\end{array}$ & (Rohrbach, 2014) \\
\hline $\mathbf{I}$ & $\begin{array}{l}19 \text { of the interviewees actively deal with Industry } 4.0 ; 22 \text { percent } \\
\text { observe and analyze the issue }\end{array}$ & (Weiß \& Zilch, 2014) \\
\hline G & $\begin{array}{l}94 \text { percent of the interviewees are aware of the importance of } \\
\text { digitization. However, only } 27 \text { percent think that they are fully or } \\
\text { almost fully prepared for the issue. }\end{array}$ & (DIHK, 2015) \\
\hline
\end{tabular}

Table 2. Overview of the enterprise sizes examined in the different studies

The results illustrate that on the one hand there is a large awareness of the importance of digitization and Industry 4.0 (= study F with 82 percent, study A with 79 percent, study B with 63 percent, study $\mathrm{G}$ with 94 percent). On the other hand, however, the activities of the enterprises to prepare for it are not very extensive yet (= study $\mathrm{F}$ with 51 percent; study D with 24 percent; study $\mathrm{G}$ with 27 percent). Study $\mathrm{H}$ and study $\mathrm{C}$ differ from this trend and need to be examined separately. The data base at hand did not allow for a separate examination of exclusively medium-sized enterprises (Computer Sciences Corp, 2015; DIHK, 2015; Freudenberg IT, 2014; GfK Enigma, 2014; Kelkar et al., 2014; PricewaterhouseCoopers AG WPG, 2014; Rohrbach, 2014; Schulze, 2014).

Hypothesis 2 examined the influence of the size of enterprises on their willingness to deal actively and passively with the subject Industry 4.0. This hypothesis can be affirmed as well. However, it is useful for the assessment to pay attention to the enterprise sizes that are examined in the different studies in advance. 


\begin{tabular}{|c|c|c|}
\hline Study & Enterprise size & Source \\
\hline $\mathbf{F}$ & SMEs between 0.5 million $€$ and 125 million $€$ & (GfK Enigma, 2014) \\
\hline $\mathrm{H}$ & One third of the interviewed SMEs have less than 250 employees & (Schulze, 2014) \\
\hline C & $\begin{array}{l}60 \text { percent SMEs with } 500 \text { to } 4.500 \text { employees; } 40 \text { percent with } 250 \\
\text { to } 499 \text { employees }\end{array}$ & (Freudenberg IT, 2014) \\
\hline $\mathbf{A}$ & $\begin{array}{l}62 \text { percent large enterprises with more than } 10,000 \text { employees; } 28 \\
\text { percent medium-sized enterprises with } 1.000 \text { to 9,999 employees; } \\
10 \text { percent with less than } 999 \text { employees }\end{array}$ & (Kelkar et al., 2014) \\
\hline B & Enterprises with at least 10 employees & (Computer Sciences Corp, 2015) \\
\hline D & $\begin{array}{l}29 \text { percent enterprises with a turnover of less than } 100 \text { million } € \text {; } 20 \\
\text { percent enterprises with a turnover between } 100 \text { and } 500 \text { million } € \text {; } \\
23 \text { percent enterprises with a turnover between } 0.5 \text { and } 1 \text { billion } € \text {; } \\
28 \text { percent enterprises with a turnover of more than } 1 \text { billion } €\end{array}$ & $\begin{array}{l}\text { (PricewaterhouseCoopers AG } \\
\text { WPG, 2014) }\end{array}$ \\
\hline E & Different enterprise sizes & (Rohrbach, 2014) \\
\hline $\mathbf{I}$ & Different enterprise sizes & (Weiß \& Zilch, 2014) \\
\hline G & Different enterprise sizes & (DIHK, 2015) \\
\hline
\end{tabular}

Table 3. Overview of the enterprise sizes examined in the different studies

The combination of Table 2 and 3 points out that in studies examining large enterprises (studies F, C, A, D, G) the values concerning the familiarity with the subject digitization/Industry 4.0 as well as acceptance, activities and awareness tend to be higher than in studies examining small enterprises. The same applies to studies with the option to differentiate between large and small enterprises (studies $\mathrm{H}, \mathrm{E}$ and I). This trend is also visible in study $A$ where the importance of Industry 4.0 decreases parallel to the enterprise size from 52 percent to 39 percent (Kelkar et al., 2014). A detailed examination of the studies D and G confirms this trend in correlation with the enterprise size, too (DIHK, 2015; PricewaterhouseCoopers AG WPG, 2014). Study I also clearly documents this trend: the larger the number of employees the larger the readiness of enterprises to deal actively or passively with the subject Industry 4.0 (Weiß \& Zilch, 2014).

Hypothesis 3 examines the question if German manufacturing enterprises according to their self-assessment see themselves economically and technically prepared for Industry 4.0. Here, we obtain a differentiated picture:

\section{Statements concerning Hypothesis 3}

(1) Primary Activities:

Study $\mathrm{F}$ confirms that enterprises are aware of the importance of digital technologies (GfK Enigma,

2014).According to the IT Innovation Readiness Index (study C) they are well on their way to successfully implementing Industry 4.0 (Kelkar et al., 2014).

\section{(2) Support Activities:}

However, according to studies $F$ and $A$ the readiness to invest in Industry 4.0 technologies is low (GfK Enigma, 2014; Kelkar et al., 2014). Study D, in contrast, delivers different results stating that there is a clear propensity to invest (PricewaterhouseCoopers AG WPG, 2014). According to the studies C and D, data processing isn't yet perceived as an important subject by the interviewed enterprises (Freudenberg IT, 2014;

PricewaterhouseCoopers AG WPG, 2014). The recruitment and further training of qualified staff for Industry 4.0 turns out to be problematic in all studies (= F, C, A, B, E, G).

\section{(3) Chances and Risks:}

It is useful to examine their perception of chances and risks to understand why risks like for example data security (studies $C, A, E, I, G$ ), doubts concerning the economic benefit and high costs (= studies A, D, I, G) potentially prevent enterprises from preparing for the subject Industry 4.0.

Table 4. Overview of the statements concerning Hypothesis 3 
Summing up, it can be concluded that enterprises - depending on their size - feel more or less well-prepared for Industry 4.0. Large enterprises tend to feel better prepared than small enterprises. In other words, SMEs still show deficits compared to large enterprises.

Implications for the practical implementation are amongst other things that enterprises are indeed willing to face digitization/Industry 4.0 , but that risks/obstacles reduce their readiness or slow down the process. Furthermore, the enterprise size plays an important role. This leads to the following practical challenges:

- insecurities, like for example data security or maturity of Industry 4.0 technologies have to be reduced;

- the benefit of Industry 4.0 has to be transferred from vision level to reality level;

- investments in Industry 4.0 technologies have to be encouraged by public funding in order to lower the barriers explicitly for SMEs;

- internal staff qualification programs and training programs for schools and universities have to be called for;

- SMEs have to be supported separately as they are less capable of coping with the financial, technological and staffing challenges than large enterprises.

SMEs are a crucial element in the supplier network of large enterprises which are already on their way towards Industry 4.0. The gap between the two enterprise categories must not be increased.

The study at hand is subject to diverse limitations. Amongst other things, the nine studies were only in parts comparable. That means that the size of the enterprises, the type of surveys, focal subjects, interviewees and the way the studies were analyzed was different. So, not every study explained the definition of SMEs that was applied for the study explicitly. In this respect we can assume that the studies generally examined SMEs, however, deviations from the strict definition of SMEs as determined by the EU Europäische Kommission, 2003 cannot be excluded. It is therefore recommendable to conduct another survey to verify the results. 


\section{References}

Ajzen, I. (2005). Attitudes, personality and behavior (2nd ed.). Mapping social psychology. Maidenhead: Open Univ. Press.

Ajzen, I., \& Fishbein, M. (1980). Understanding attitudes and predicting social behavior (Pbk. ed.). Englewood Cliffs, N.J: Prentice-Hall.

Arthur, D. (2013). Industrie 4.0 und Integrated Industry: SegenoderFluchfür die deutsche Industrie?. A vailable on line in : http://www.adlittle.de/bem-pressemeldungen de.html? \&no cache $=1 \&$ view $=413$. (Last access date: March 11th, 2015).

Bundesverband Informationswirtschaft, Telekommunikation und neue Medien e.V. (2015). Plattform Industrie 4.0. Available online in: http://www.plattform-i40.de/. (Last access date: March 11th, 2015).

Bundeszentrale für politische Bildung (2011). Industrielle Revolution. Available online in: http://www.bpb.de/nachschlagen/lexika/politiklexikon/17631/industrielle-revolution. (Last access date: March 11th, 2015).

Carnegie Mellon University (n.d.). Value Chain. Available online in: http://www.cmu.edu/erm/concepts/value.html. (Last access date: March 11th, 2015).

Computer Sciences Corp (2015). CSC - Studie Industrie 4.0: Ländervergleich Dach. Available online in: http://assets1.csc.com/de/downloads/Ergebnisse CSC-Studie 4.0.pdf. (Last access date: March 11th, 2015).

DIHK (2015). Wirtschaft 4.0: Große Chancen, viel zu tun. Available online in: http://www.dihk.de/presse/meldungen/2015-02-05-unternehmensbarometer-digitalisierung. (Last access date: March 11th, 2015).

Dörfler, M. (2013). Industrie 4.0 ist im Mittelstand noch nicht angekommen. Available online in: http://www.marktundmittelstand.de/nachrichten/produktion-technologie/industrie-40-ist-im-mittelstand-nochnicht-angekommen/. (Last access date: March 11th, 2015).

Eisert, R. (2014a). Mittelständler verpassen die Zukunftstrends. Available online in: http://www.wiwo.de/unternehmen/mittelstand/industrie-4-0-mittelstaendler-verpassen-diezukunftstrends/10004718.html. (Last access date: March 11th, 2015).

Eisert, R. (2014b). Sind Mittelständler auf Industrie 4.0 vorbereitet?. Available online in: http://www.wiwo.de/unternehmen/mittelstand/innovation-readiness-index-sind-mittelstaendler-auf-industrie-4-0vorbereitet/10853686.html. (Last access date: March 11th, 2015). 
Europäische Kommission (2003). Was ist ein KMU?. Available online in: http://ec.europa.eu/enterprise/policies/sme/facts-figures-analysis/sme-definition/index de.htm. (Last access date: March 11th, 2015).

Freudenberg IT (2014). IT Innovation Readiness Index 2014. Available online in: http://www.freudenberg-it.com/de/it-innovation-readiness-index-2014/ueberblick-2014.html. (Last access date: March 11th, 2015).

GfK Enigma (2014). Umfrage in mittelständischen Unternehmen zum Thema Digitalisierung Bedeutung für den Mittelstand im Auftrag der DZ Bank. Available online in: https://www.deutschland-made-bymittelstand.de/mittelstandskampagne2014/static/uploads/DZ_Bank_Digitalisierung_Grafiken.pdf. (Last access date: March 11th, 2015).

Herkommer, G. (2014). Schlechtes Zeugnis für Chefs, Mitarbeiter und die Politik. Available online in: http://www.computer-automation.de/unternehmensebene/engineering/artikel/115509/. (Last access date: March 11th, 2015).

Johannes Gutenberg Universität Mainz, Psychologisches Institut (2012). Gliederung für systematische Reviews. Available online in: http://bildungswissenschaften.psychologie.sowi.unimainz.de/Dateien/lit_arbeit.pdf. (Last access date: March 11th, 2015).

Kelkar, O., Heger, R., \& Dao, D.-K. (2014). Industrie 4.0 - Eine Standortbestimmung der Automobil- und Fertigungsindustrie. Available online in: http://www.mhp.com/fileadmin/mhp.de/assets/studien/MHP-Studie_Industrie4.0_V1.0.pdf. (Last access date: March 11th, 2015).

Knop, C. (2014). Dem deutschen Mittelstand ist die Digitalisierung egal. Available online in: http://www.faz.net/aktuell/wirtschaft/wirtschaftspolitik/deutsche-betriebe-investieren-kaum-in-digitalen-ausbau13146623.html. (Last access date: March 11th, 2015).

Maaß, S. (2015). Bei der digitalen Strategie müssen viele Chefs passen. Available online in: http://www.welt.de/wirtschaft/karriere/article136475514/Bei-der-digitalen-Strategie-muessen-viele-Chefspassen.html. (Last access date: March 11th, 2015).

Maier, A., \& Student, D. (2015). Industrie 4.0 - der große Selbstbetrug. Available online in: http://www.manager-magazin.de/magazin/artikel/digitale-revolution-industrie-4-0-ueberfordert-deutschenmittelstand-a-1015724.html. (Last access date: March 11th, 2015).

Perspektive Mittelstand (2015). Industrie 4.0 macht Mittelstand zu schaffen. Available online in: http://www.perspektive-mittelstand.de/Industrie-40-macht-Mittelstand-zu-schaffen/managementwissen/6093.html. (Last access date: March 11th, 2015). 
PricewaterhouseCoopers AG WPG (2014). PwC- und Strategy\&-Studie: Industrie 4.0 hat hohes Nutzenpotenzial für deutsche Unternehmen. Available online in: http://www.pwc.de/de/digitaletransformation/pwc-studie-industrie-4-0-steht-vor-dem-durchbruch.jhtml. (Last access date: March 11th, 2015).

Ressing, M., Blettner, M., \& Klug, S.J. (2009). Systematic literature reviews and metaanalyses: part 6 of a series on evaluation of scientific publications. Deutsches Ärzteblatt international, 106(27), 456-463.

Reuters (2014). 501 deutsche Unternehmen sind Umsatzmilliardäre. Available online in: http://www.handelsblatt.com/unternehmen/management/statistisches-bundesamt-501-deutsche-unternehmensind-umsatzmilliardaere/9631630.html. (Last access date: March 11th, 2015).

Rickmann, H. (2014). Verschläft der deutsche Mittelstand einen Megatrend?. Available online in: http://www.focus.de/finanzen/experten/rickmann/geringer-digitalisierungsgrad-verschlaeft-der-deutschemittelstand-einen-megatrend_id_3973075.html. (Last access date: March 11th, 2015).

Rohrbach, T. (2014). Studie: Deutsche Wirtschaft hält sich für Industrie 4.0-Weltmeister. Available online in: http://www.staufen.ag/de/news-events/news/article/2014/10/studie-deutsche-wirtschafthaelt-sich-fuer-industrie-40-weltmeister.html. (Last access date: March 11th, 2015).

Schmidt, H. (2014). Der Hype um Industrie 4.0 ist vorbei: Verspielt Deutschland seine Zukunft?. Available online in: http://t3n.de/news/industrie-4-0-deutschland-585460/. (Last access date: March 6th, 2015).

Schulze, A. (2014). Industrie 4.0 steht noch ganz am Anfang. Available online in: http://www.flyacts.com/blog/industrie-4-0-steht-noch-ganz-am-anfang/. (Last access date: March 11th, 2015).

Stamm, H., \& Schwarb, T.M. (1995). Metaanalyse. Eine Einführung. Zeitschrift für Personalforschung, 9(1), 5-25. Available online in: http://www.hampp-verlag.de/Archiv/1 95 Stamm.pdf. (Last access date: March 11th, 2015).

Statistisches Bundesamt (2014a). Kleine \& mittlere Unternehmen (KMU), Mittelstand. Available online in:

https://www.destatis.de/DE/ZahlenFakten/GesamtwirtschaftUmwelt/UnternehmenHandwerk/KleineMittlereUnterneh menMittelstand/KleineMittlereUnternehmenMittelstand.html. (Last access date: March 11th, 2015).

Statistisches Bundesamt (2014b). Produzierendes Gewerbe und Dienstleistungen im Überblick. Available online in: https://www.destatis.de/DE/Publikationen/StatistischesJahrbuch/ProdGewerbeDienstleistungen.pdf? blob=publicationfile. (Last access date: March 11th, 2015). 
Unternehmer Position Nord (2015). Sorge hemmt digitalen Fortschritt. Available online in: http://www.unternehmerpositionen.de/wirtschaft/2015-02/sorge-hemmt-digitalen-fortschritt/. (Last access date: March 11th, 2015).

Weiß, M., \& Zilch, A. (2014). Große Anwenderstudie zu Industrie 4.0 in Deutschland - Hohe Potenziale, aber auch Unsicherheit und unklare Verantwortungen. Available online in: http://www.experton-group.de/press/releases/pressrelease/article/grosse-anwenderstudie-zu-industrie-40-indeutschland-hohe-potenziale-aber-auch-unsicherheit-und-unklare-verantwortungen.html. (Last access date: March 11th, 2015).

Wirtschaftsrat der CDU e. V. (2015). Die Stimme der Sozialen Marktwirtschaft. Available online in: http://www.wirtschaftsrat.de/wirtschaftsrat.nsf/id/home-de. (Last access date: March 11th, 2015).

Article's contents are provided on an Attribution-Non Commercial 3.0 Creative commons license. Readers are allowed to copy, distribute and communicate article's contents, provided the author's and Journal of Industrial Engineering and Management's names are included. It must not be used for commercial purposes. To see the complete license contents, please visit http://creativecommons.org/licenses/by-nc/3.0/.
} 